\title{
A clinicopathological study of benign Hodgkin's disease
}

\author{
P. J. DAWSON' ${ }^{1}$ AND C. V. HARRISON \\ From the Department of Pathology, Postgraduate Medical School, Ducane Road, London
}

SYNOPSIS A series of 44 cases of benign Hodgkin's disease is reported. The condition occurs most commonly between the ages of 15 and 35 years and affects men more often than women. The presenting symptom is painless lymphadenopathy, frequently in the neck, and often confined to a single group of nodes. The histological features are the presence of Sternberg-Reed cells in a background of mature lymphocytes intermingled with a small number of reticulum cells. Mitotic figures are usually present only in the Sternberg-Reed cells. The prognosis is good; $93 \%$ of cases survive five years and $85 \% 10$ years. About one-quarter of the cases show transition to classical Hodgkin's disease after a period of five or more years and die with widely disseminated Hodgkin's disease. Biopsy-excision followed by radiotherapy is the treatment of choice.

In 1952 one of us reported six cases of benign Hodgkin's disease (Harrison, 1952). We believed that it was a recognizable histological entity but were then uncertain as to its behaviour. In particular, we did not know to what extent the ultimate prognosis was better than that of classical Hodgkin's disease, especially if the latter was seen and treated in an early stage. Since 1952 we have had the opportunity of studying a considerable number of cases, largely thanks to the kindness of our colleagues. In the present paper we have attempted to define the histological features more closely and to determine whether the separation of this group is justified in terms of ultimate prognosis.

\section{NOMENCLATURE}

Jackson and Parker (1944), who first described the condition, called it 'Hodgkin's paragranuloma'; Robb-Smith (1947) described an apparently similar condition under the name of 'lympho-reticular medullary reticulosis'. Lumb (1954) has used the title 'reticular lymphoma' and Symmers (1958) has suggested 'indolent Hodgkin's disease'. In the present paper we propose to use the name 'benign Hodgkin's disease' which we coined in our earlier work. (The term 'classical Hodgkin's disease' will be used for purposes of clarity for the widely recognized and

Received for publication December 1960

'Present address: Department of Pathology, University of California Medical Center, San Francisco 22, California, U.S.A. more usual form of the disease which some call Hodgkin's granuloma.)

\section{LITERATURE}

Rosenthal (1936) first presented a histological classification of Hodgkin's disease based on the proportion of lymphocytes to reticulum cells. He found that a higher proportion of lymphocytes correlated with a longer survival. Jackson (1937, 1939) and Jackson and Parker (1944, 1947) first defined the condition which they called paragranuloma and showed that the prognosis was clearly better than that of ordinary Hodgkin's disease. Since then, various workers have described series of similar cases (Robb-Smith, 1947; Wright, 1956, 1960; Bonenfant, 1954; Lumb, 1954; Trautmann, 1954, 1959; Marshall, 1956; Symmers, 1958). There is general agreement on the broad definition of the histology and on the improved prognosis. In spite of this, the actual cases remain difficult diagnostic problems. We hope to be able to define the diagnostic criteria a little more closely and to show that the prognosis is so strikingly better that an accurate diagnosis is of great clinical importance.

\section{MATERIAL}

We have collected all the examples of possible benign Hodgkin's disease, both from our own hospital and from cases sent in by our colleagues. These were examined without any knowledge of the 


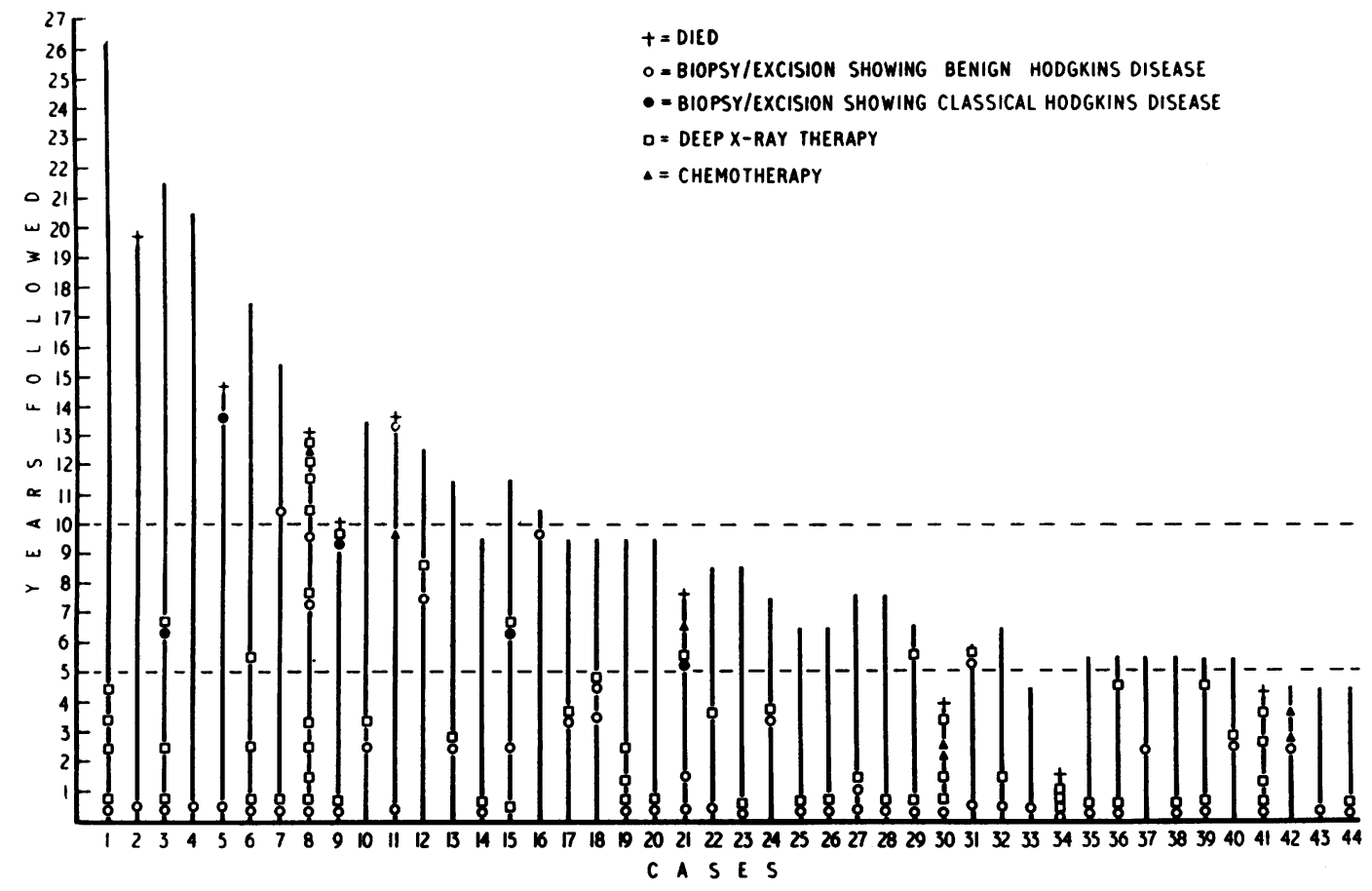

FIG. 1. Histogram summarizing the duration, forms of therapy, recurrences, and follow-up in all 44 patients.

clinical course. Forty-five cases were found which, on purely histological grounds, we considered to be examples of benign Hodgkin's disease and a followup was obtained on these. This was successful in all cases except one, although we have good reason for believing the patient to be alive seven years after the onset of the disease. Because of the long course of the disease, there seemed little point in considering cases of very recent onset, so that patients who had suffered from the disease for less than three years were excluded.

There were then 44 cases of benign Hodgkin's disease selected on morphological grounds with a minimum follow-up period of three years; in fact, all were followed for four years or longer. Fifty-six biopsies from these cases were available for study. Multiple biopsies were available in 10 patients; five of these showed transition to classical Hodgkin's disease. One further biopsy also showed benign Hodgkin's disease, but was too poor technically for detailed study. We were unable to obtain the first biopsy in Case 7; it was reported elsewhere as Hodgkin's disease and because the second biopsy showed typical benign Hodgkin's disease we have presumed that the first was similar and, although marked on Fig. 1, it is not, of course, included in our analysis. A further four biopsies showed norma lymphoid tissue only and are not shown in Fig. 1] The cases are numbered and successive biopsies of the same patient designated by the letters A, B, and C.

Because of the rarity of the condition and because many of our cases were sent to us for an opinion by. other pathologists, only paraffin-blocked materiap was available, and in some cases only a single haematoxylin-and-eosin-stained section was obtain-? able. Silver-impregnated reticulin preparations weres made wherever possible and a few other specia?. stains, notably methyl violet for amyloid, were used to clarify specific points. All histological examinations were made without knowledge of the subse quent course of the patient.

In order to clarify the boundary between benigu and classical Hodgkin's disease a control series of 43 biopsies from 42 consecutive cases of classica Hodgkin's disease seen in the department from $195 f^{\circ}$ to 1955 were also studied.

\section{CLINICAL FEATURES}

Details of the presenting features are summarized in Table I. The age of onset varied from 6 to $7 \widehat{6}$ 
TABLE I

\section{CLINICAL DETAILS}

\begin{tabular}{|c|c|c|c|}
\hline $\begin{array}{l}\text { No. of } \\
\text { Case }\end{array}$ & $\begin{array}{l}\text { Age at } \\
\text { Onset }\end{array}$ & $\operatorname{Sex}$ & Sites of Disease when First Seen \\
\hline 1 & 24 & $\mathbf{M}$ & Neck (R), axillae, groin (L) \\
\hline 2 & 57 & $\mathbf{F}$ & Neck (L), neck (R) \\
\hline 3 & 19 & $\mathbf{M}$ & Axillae, groins \\
\hline 4 & 12 & $\mathbf{M}$ & Neck (R) \\
\hline 5 & 15 & $\mathbf{M}$ & Neck \\
\hline 6 & 31 & $\mathbf{F}$ & Neck (L) \\
\hline 7 & 18 & $\mathbf{F}$ & Neck (L) \\
\hline 8 & 12 & $\mathbf{M}$ & Neck (R) \\
\hline 9 & 33 & $\mathbf{M}$ & Neck (R) \\
\hline 10 & 16 & $\mathbf{M}$ & Neck (bilateral), axillae \\
\hline 11 & 22 & $\mathbf{M}$ & Neck (L), axillae \\
\hline 12 & 21 & $\mathbf{M}$ & Neck (L) \\
\hline 13 & 33 & $\mathbf{M}$ & Axilla (R) \\
\hline 14 & 9 & $\mathbf{M}$ & Neck (R) \\
\hline 15 & 6 & $\mathbf{F}$ & Neck (L) \\
\hline 16 & 23 & $\mathbf{F}$ & Mediastinum \\
\hline 17 & 20 & $\mathbf{M}$ & Neck \\
\hline 18 & 29 & $\mathbf{M}$ & Neck \\
\hline 19 & 30 & $\mathbf{F}$ & Neck (L), mediastinum \\
\hline 20 & 15 & $\mathbf{M}$ & Neck (L) \\
\hline 21 & 47 & $\mathbf{M}$ & Neck (L), groin (R) \\
\hline 22 & 18 & $\mathbf{M}$ & Axillae \\
\hline 23 & 29 & $\mathbf{M}$ & Axilla ( $R$ ) \\
\hline 24 & 58 & $\mathbf{M}$ & Neck (R) \\
\hline 25 & 21 & $\mathbf{M}$ & Neck \\
\hline 26 & 25 & $\mathbf{M}$ & Neck (R) \\
\hline 27 & 28 & $\mathbf{M}$ & Neck (R) \\
\hline 28 & 20 & $\mathbf{M}$ & Neck (L) \\
\hline 29 & 23 & $\mathbf{M}$ & Neck (L) \\
\hline 30 & 34 & $\mathbf{M}$ & Neck (R) \\
\hline 31 & 8 & $\mathbf{M}$ & Neck (L) \\
\hline 32 & 36 & $\mathbf{M}$ & Neck (L) \\
\hline 33 & 30 & $\mathbf{F}$ & Neck, neck (L) \\
\hline 34 & 70 & $\mathbf{F}$ & Axillae, spleen \\
\hline 35 & 50 & $\mathbf{M}$ & Neck \\
\hline 36 & 17 & $\mathbf{M}$ & Neck $(R)$, mediastinum \\
\hline 37 & 17 & $\mathbf{M}$ & Axillae \\
\hline 38 & 26 & $\mathbf{F}$ & Neck (L) \\
\hline 39 & 16 & $\mathbf{F}$ & Groin (R) \\
\hline 40 & 22 & $\mathbf{F}$ & Neck (L) \\
\hline 41 & 38 & $\mathbf{F}$ & Neck (R) \\
\hline 42 & 30 & $\mathbf{M}$ & Axilla (R) \\
\hline 43 & 25 & $\mathbf{M}$ & Groin (L) \\
\hline 44 & 51 & $\mathbf{F}$ & Neck (R) \\
\hline
\end{tabular}

years; in 31 cases the disease began between the ages of 15 and 35 years. Thirty-one cases occurred in men and 13 in women, giving a sex ratio of $2 \cdot 4$ to 1 . In all cases where the patient complained of symptoms relevant to the disease the presenting complaint was painless enlargement of lymph nodes, and in 36 of the 44 cases these were situated in the neck. The cases were staged when first seen using the criteria similar to those of Peters and Middlemiss (1958), except that stage II was not subdivided.

Thirty-four cases belonged to stage $I$, that is to say, had lymph node involvement confined to one group of nodes, six cases belonged to stage II, and four to stage III. Pain was not a feature. Constitutional symptoms were present in two cases in stage I and in one case in stage II. In one patient the spleen was enlarged when she was first seen; the liver was only noted to be enlarged in the terminal stages of the disease. One patient developed a swelling in one buttock which responded to radiotherapy; unfortunately, it was not biopsied. In one case enlarged tonsils were removed; histologically they are said to have shown the typical appearances of benign Hodgkin's disease. Unfortunately, the sections are not now available.

The interval between the onset of symptoms (or signs) and the diagnostic biopsy varied from two weeks to nine years. In six cases the duration of symptoms before biopsy was not recorded, or the lymphadenopathy was an incidental finding in patients attending for other reasons. These cases are recorded as having a biopsy in the first year. In 28 of the remaining 38 cases the interval between the onset of symptoms and biopsy was one year or less, in five cases it was two years, in three cases it was three years, and in the other two cases seven and nine years respectively. These intervals are well substantiated and in the nine-year interval is supported by indisputable radiological evidence. Because of this, the duration of the disease has been measured from the first definite lymph node enlargement; in all cases a positive biopsy has subsequently been obtainned from the group of nodes first enlarged.

\section{PATHOLOGY}

The affected lymph nodes varied in size between 3 and $50 \mathrm{~mm}$. in diameter, but the majority were between 10 and $30 \mathrm{~mm}$. in diameter. The nodes were discrete and firm, but not hard. Individual nodes were bound together by loose connective tissue; their cut surfaces were smooth, homogeneous, and pale pink or light grey. These appearances are not distinctive and the condition cannot be distinguished from other tumours of lymphoid tissue by naked-eye examination alone.

Partial involvement of affected nodes was surprisingly common, occurring in 16 of 51 biopsies. The uninvolved part of the node was usually small and usually amounted to several follicles surviving near the periphery (Figs. 2, 3, and 4). However, in five biopsies a substantial part of the node (an estimated $20 \%$ ) retained its normal structure.

Silver-impregnated preparations were available in 41 of 51 biopsies and in our experience were of considerable diagnostic value. They always showed that the normal reticulin pattern in the affected part of the node was completely lost, and incidentally showed up by contrast the frequent presence of small unaffected portions. In the affected part the normal reticulin pattern was replaced by one of three abnormal patterns. In 13 biopsies there was a delicate, sometimes incomplete, meshwork of fine 

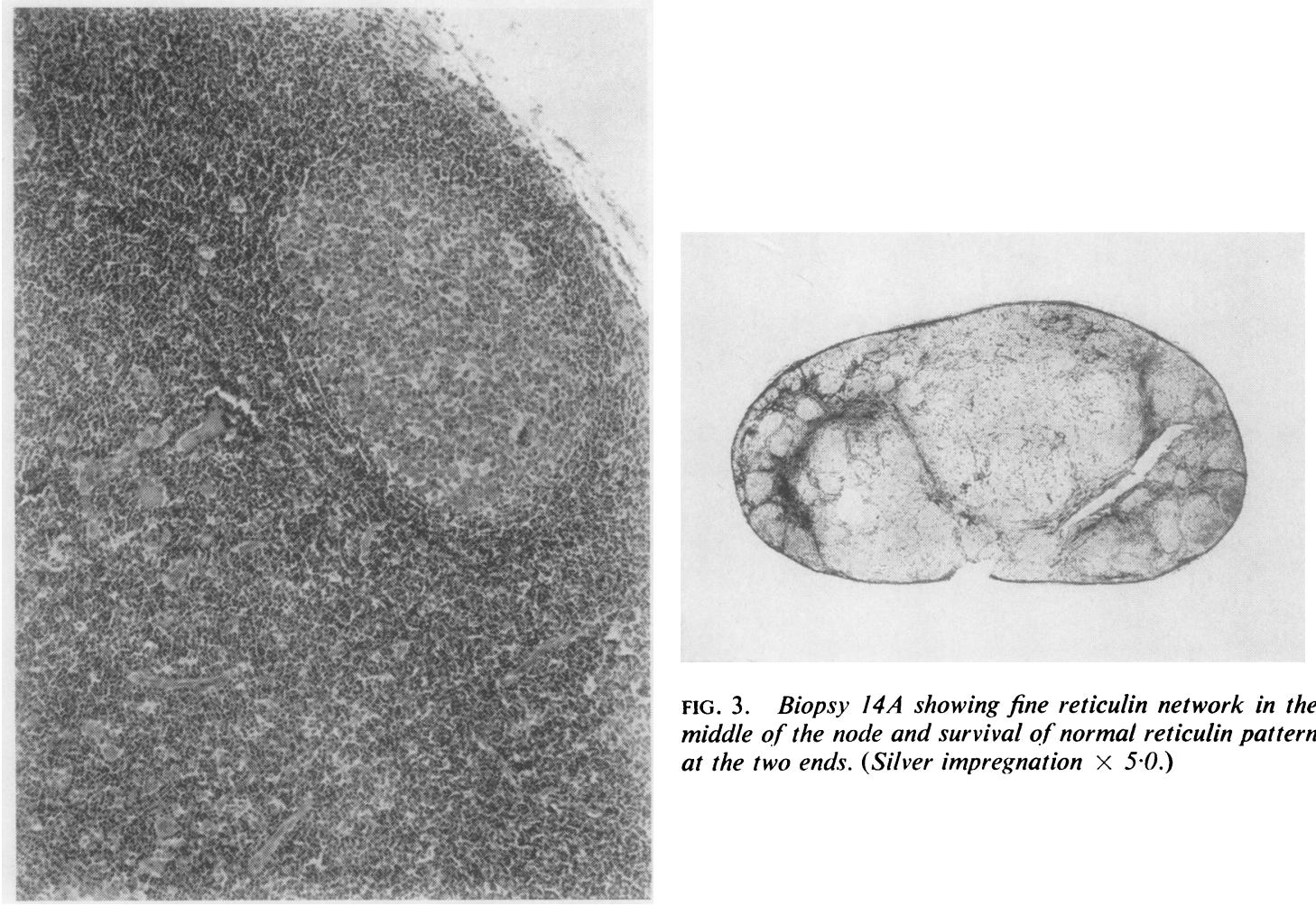

FIG. 3. Biopsy 14A showing fine reticulin network in the $\vec{\oplus}$ middle of the node and survival of normal reticulin pattern. at the two ends. (Silver impregnation $\times 5 \cdot 0$.)

FIG. 2. Biopsy $8 A$ from a case of benign Hodgkin's disease showing incomplete involvement of the node. (Note surviving follicle under capsule at bottom left.) (Haematoxylin and eosin $\times 100$.)

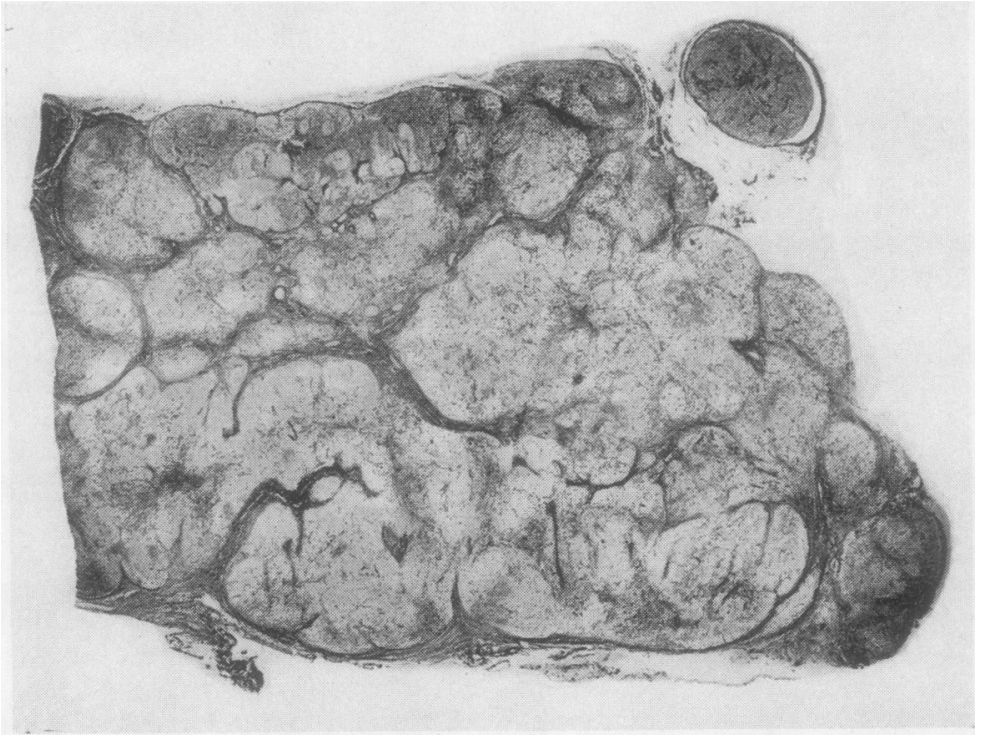

FIG. 4. Biopsy $12 B$ showing lobulation by reticulin. (Note surviving normal structure in middle by upper border.) (Silver impregnation $\times 5 \cdot 2$.) 


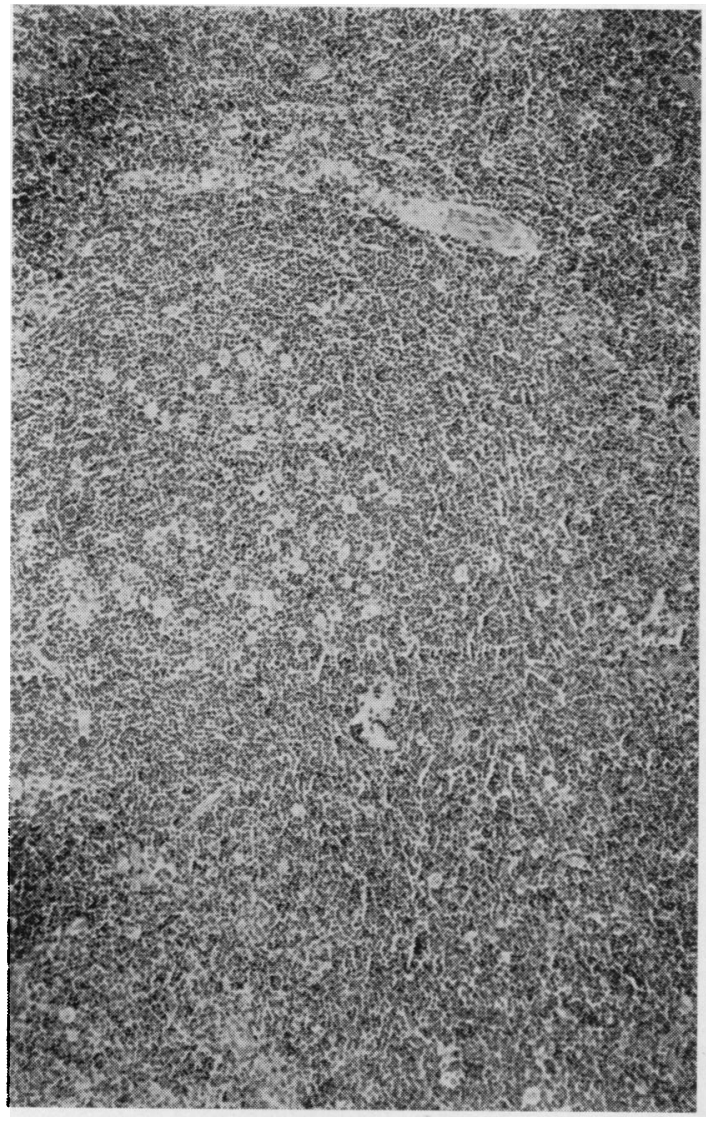

FIG. 6. Biopsy $32 \mathrm{~A}$ from a case of benign Hodgkin's disease, showing the general appearance of massed lymphocytes with a few giant cells. (Haematoxylin and eosin $\times 100$.)

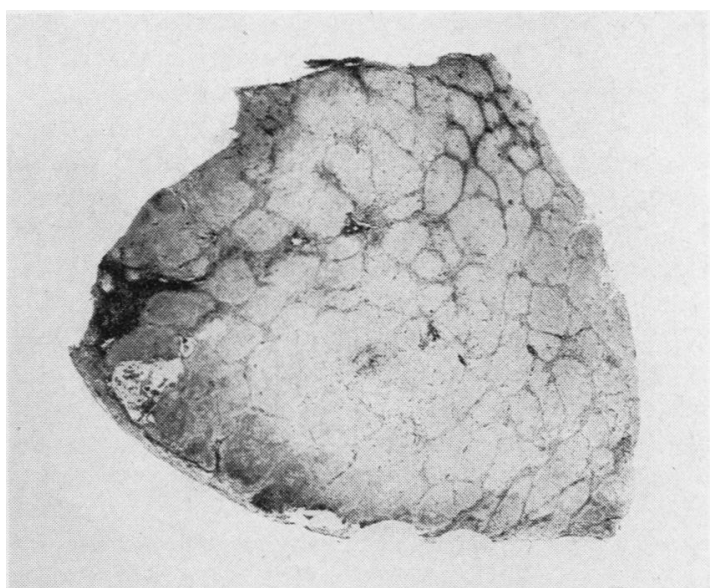

FIG. 5. Biopsy 43A showing a follicular pattern. (Silver impregnation $\times 5 \cdot 2$.)

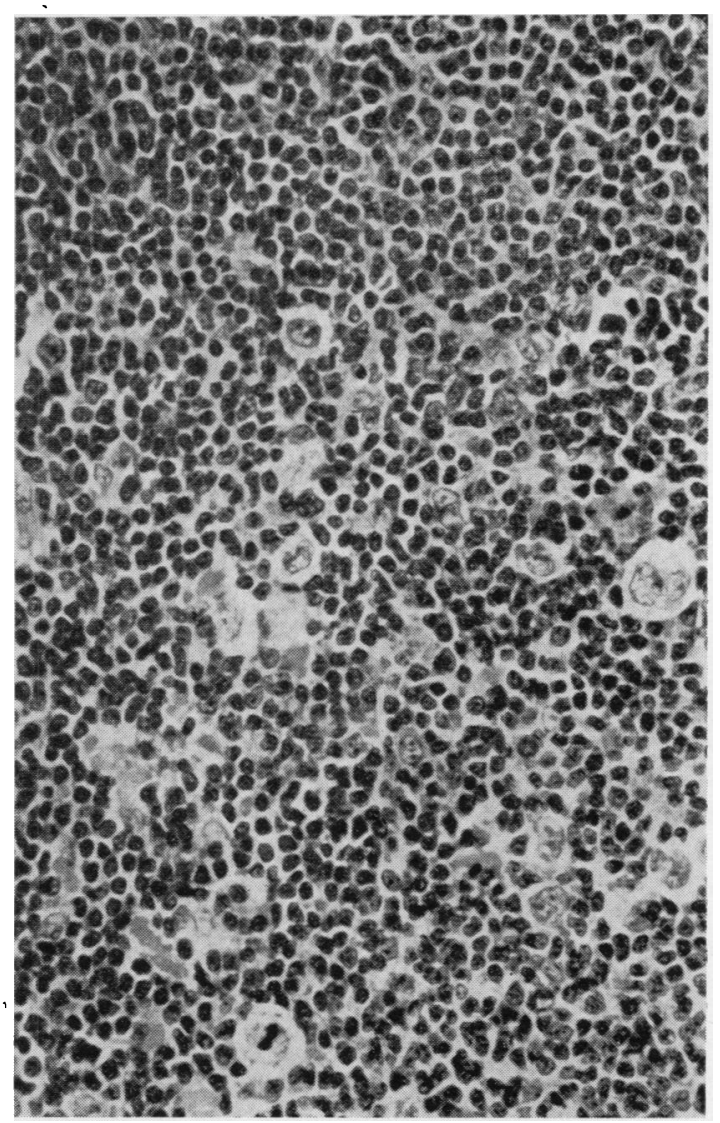

FIG. 7. Same case as Fig. 6, but at a higher magnification showing lymphocytes and giant cells. (Note mitosis in a Sternberg-Reed cell near bottom margin.) (Haematoxylin and eosin $\times 380$.) 
fibrils, usually less dense than that of a normal node (Fig. 3). In 16 biopsies a similar delicate meshwork was divided into lobules of variable size by denser bands of reticulin fibrils (Fig. 4). In 10 biopsies there was a pattern not unlike that of giant follicular lymphoma. Here the tissue was divided into a series of uniform rounded masses 2 to $4 \mathrm{~mm}$. diameter by reticulin bands with very sparse fibrils within the 'follicles' (Fig. 5). A heavy increase of reticulin was unusual and collagenous bands were seen in only two biopsies. Generally the density of the reticulin was considerably less than in ordinary Hodgkin's disease. In many nodes, including those that appeared to be totally involved, part of the peripheral sinus could still be made out. In ordinary stained sections lymphocytes comprised the majority of the cells in the affected nodes (Figs. 6 and 7). They were morphologically indistinguishable from the small lymphocytes seen in normal nodes and did not show mitotic figures. The reticulum cells, which lay free in the pulp among the lymphocytes, were in the minority. They averaged about $10 \mu$ in diameter and had a poorly outlined pink cytoplasm. The nucleus, which occupied most of the cell, had a sharply drawn nuclear membrane, a finely dotted chromatin net and, sometimes, a small dark nucleolus. Mitoses were not commonly seen in these cells and were only present in any number in eight biopsies from seven cases. In one of these cases we have histological evidence of transition to classical Hodgkin's disease, and a further three died with a clinical diagnosis of generalized Hodgkin's disease. In seven biopsies sarcoid-like aggregates of histiocytes were observed. These cells were larger than those just described, with a smaller nucleus and a brightly eosinophilic cytoplasm. Of these seven cases two showed histologically transition to classical Hodgkin's disease and four died, three of generalized Hodgkin's disease.

The relative number of lymphocytes and reticulum cells was found to be of the greatest importance. These were estimated and expressed as a percentage of the total of both types of cell. In 50 biopsies, $80 \%$ or more of the cells were lymphocytes and $20 \%$ or less reticulum cells. In the remaining biopsy the percentages were 75 and 25 respectively. In 36 biopsies, $90 \%$ or more of the background cells were lymphocytes (Fig. 6).

Sternberg-Reed cells were present in all biopsies and were regarded as essential to the diagnosis. They varied in size from $15 \mu$ to $45 \mu$ in diameter, but the majority lay within the range $15 \mu$ to $25 \mu$. Transitions between reticulum cells and SternbergReed cells could be observed fairly readily and for this reason a minimum diameter of $15 \mu$ was accepted for the latter (Smetana and Cohen, 1956). Their cytoplasm was poorly outlined, pale pink, and granu- lar, but often vacuolated so that all that could be $\stackrel{0}{\vec{\sigma}}$ seen was a halo around the nucleus. The nucleus was big in relation to the size of the cell. Sometimes $\overrightarrow{\vec{F}}$ it appeared single and round, sometimes it wasfolded or lobed and sometimes there appeared to $\frac{}{0}$ be two or more round, discrete nuclei. The nuclear $\overline{\bar{c}}$. membrane was finely drawn, with a few chromatin $\vec{\Phi}$ dots upon it. A striking feature was the presence of one or two large eosinophilic nucleoli measuring ${ }^{\infty}$ from $1 \mu$ to $4 \mu$ in diameter. Mitoses, both normal $\vec{\circ}$ and abnormal, were a constant feature of the $\overrightarrow{ }$ Sternberg-Reed cells and in only one case were ${ }_{\sigma}^{\omega}$ they difficult to find. On average, nearly $3 \%$ of all Sternberg-Reed cells were in mitrosis (Fig. 7). There was no apparent correlation between the $\overrightarrow{+}$ number of mitoses and the liability to transition to $\omega$ classical Hodgkin's disease. The number of $\frac{N}{6}$ Sternberg-Reed cells present varied widely both ${ }_{0}^{\circ}$ from node to node and in different parts of the same section. Estimated on a one to four plus system their $\vec{z}$ distribution was: one plus in 14 biopsies, two plus in 22 biopsies, and three plus in 15 biopsies. In no instance were very large numbers of Sternberg- $\stackrel{\odot}{\circ}$ Reed cells seen. In 32 biopsies they were scattered.singly through the lymphocytic background, in 18 응 biopsies they were aggregated to form small loose clusters, and in one biopsy they formed large clusters.

Eosinophils were present in small numbers in $\stackrel{\circ}{\varnothing}$ seven biopsies, but never in the large numbers $\overrightarrow{\overrightarrow{0}}$ observed in some cases of classical Hodgkin's 3 disease. Neutrophil polymorphs were present on one $\bar{\supset}$ biopsy, and small numbers of plasma cells in four.:

Amyloid, staining metachromatically with methyl violet, was present in one biopsy and paramyloid in 21.

Caseation and necrosis were not seen, save in one biopsy where there were a few microscopic areas of $\frac{\bigcirc}{3}$ necrosis. Capsular invasion was not seen.

\section{DIAGNOSTIC CRITERIA}

In our experience the following criteria need to beN fulfilled before a diagnosis of benign Hodgkin's disease can be made. The normal architectural 0 pattern of the node in a reticulin preparation must $\omega$ be destroyed in the affected part, and should be replaced by one of the three patterns describedo above. Sternberg-Reed giant cells must be present. At least $80 \%$ of the cells must be small lymphocytes ${ }^{\text {? }}$ and mitoses in these cells should be absent or rare. Eosinophils should be scanty or absent.

\section{DIFFERENTIAL DIAGNOSIS}

Three other malignant lymphomas cause diagnostic 
difficulty: lymphosarcoma, giant follicular lymphoma, and classical Hodgkin's disease.

In lymphosarcoma the reticulin pattern shows a loose meshwork like that of one of the patterns in benign Hodgkin's disease. The lymphocytes which form the great majority of the cells show anisocytosis, nuclear variation, and mitotic figures. Small reticulum cells may sometimes be found amongst the lymphocytes but these should not be mistaken for Sternberg-Reed giant cells which do not occur in lymphosarcoma. Capsular invasion is common, a feature which is not seen in benign Hodgkin's disease.

Giant follicular lymphoma can only be confused with the type of benign Hodgkin's disease showing an apparent follicular pattern. Two criteria differentiate these: in giant follicular lymphoma the rounded lesions are lymphoid follicles whereas in benign Hodgkin's disease they are aggregations of lymphocytes without real follicular arrangement. In benign Hodgkin's disease Sternberg-Reed giant cells are present even if scanty: they are absent from giant follicular lymphoma. The differential diagnosis from classical Hodgkin's disease is less clear because the differences are quantitative rather than qualitative. In order to define the differences more closely we compared our 44 cases of benign Hodgkin's disease with 43 cases of classical Hodgkin's disease. In the latter partial involvement of the node was seen only five times. In silver-impregnated preparations the normal architecture was always destroyed and was usually replaced by a tangled network of fibres appreciably denser than in the benign form. The total density of the reticulin was excessive in about two-thirds of cases of classical Hodgkin's disease but in the other third it was not appreciably denser than in the benign form. In seven cases the reticulin showed a fine lobulation like that of one pattern of benign Hodgkin's disease and in another eight there was a similar but much denser lobulation with true collagen. In haemalum-and-eosin-stained sections lymphocytes were always present and they were not morphologically different from those of benign Hodgkin's disease nor did they show mitotic figures. Reticulum cells were always present in much greater numbers than in benign Hodgkin's disease and generally they were larger and more pleomorphic. Mitoses could always be found in them, though they were numerous in only one case. Sarcoid-like aggregates were seen in only five cases. A constant difference was seen in the proportion of reticulum cells to lymphocytes. Whereas in benign Hodgkin's disease reticulum cells did not exceed $20 \%$, they always exceeded $35 \%$ in the classical disease (Fig. 9). Sternberg-Reed giant cells were present by definition in both conditions but they were generally more numerous in the classical disease. Using the same grading as we used in benign Hodgkin's disease, we found 1 plus in only five cases, 2 plus in 19, and 3 or 4 plus in the other 19.

In all cases mitoses were observed in the SternbergReed cells and on average they were present in $5 \%$. In 13 cases Sternberg-Reed cells were present in large closely packed groups.

Eosinophils were present in 38 of 43 biopsies and in 29 of these they were present in moderate or large numbers. Neutrophil polymorphs were present in 18 biopsies, in half of them in moderate or large numbers, while plasma cells were present in 21 biopsies, in seven in moderate or large numbers.

Amyloid was not seen but paramyloid was present in 19 biopsies. Caseation was not seen but necrosis was present in nine biopsies and capsular invasion was present in four.

It was originally felt that it might be necessary to create an intermediate group of cases lying midway between benign and classical Hodgkin's disease. Initially, about eight cases fell into this group. Later, after the distinguishing criteria were better established these were re-examined, when they all seemed to fall quite definitely either into the benign or classical group.

\section{COURSE OF BENIGN HODGKIN'S DISEASE}

This is summarized in Fig. 1. Characteristically it is slow, and after radiotherapy most patients enjoy a long period of remission during which, although small shotty nodes may still be palpable at the original site, they usually feel quite well. After a varying period many cases relapse. In our series, the longest survival was 26 years from the onset of the disease: another patient who died in the nineteenth year of her illness never received any specific treatment and was only incapacitated by her illness in the last year of her life. The shortest survival was of a patient who died after an illness lasting 15 months. She had widespread lymphadenopathy and a palpable spleen when first seen, so that there is some doubt as to whether the biopsy was truly representative. A total of nine out of our 44 patients have died after periods lasting from 15 months to 19 years, four after more than 10 years. In three of the patients who died there was histological evidence of transition to classical Hodgkin's disease, and this was suggested by the clinical course in another four. We have histological evidence of this transition in two other patients, both of whom are alive and well five and 15 years later respectively (Figs. 8 and 9). The intervals between successive biopsies showing benign and classical Hodgkin's disease in the cases 


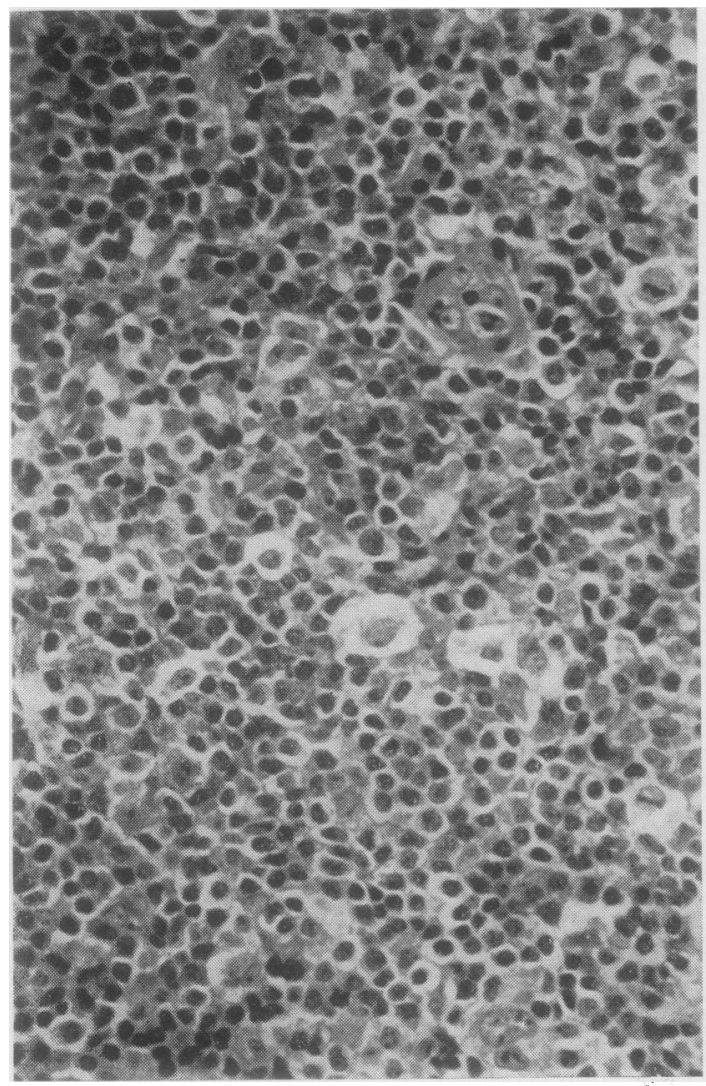

FIG. 8. Biopsy $3 A$, the original biopsy from a case of benign Hodgkin's disease.

(Haematoxylin and eosin $\times 380$.)

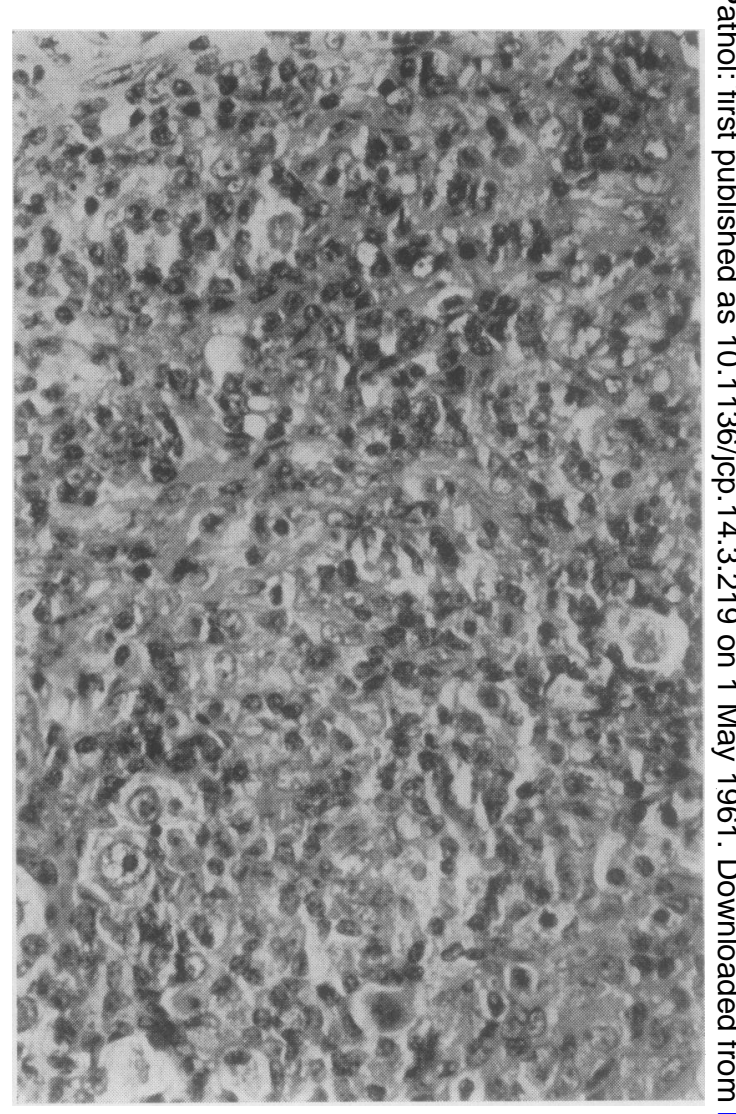

FIG. 9. Biopsy $3 B$, six years after biopsy $3 A$, now showing classical Hodgkin's disease. The majority of the cells arè now reticulum cells and lymphocytes are scanty. in which transition occurred varied from four to 13 years.

In the other two fatal cases post-mortem examination revealed generalized amyloidosis, and in both death was due to uraemia consequent upon renal vein thrombosis. In one case the benign Hodgkin's disease was confined to a single group of nodes in the neck. In the other there was no trace of Hodgkin's disease and, although the clinical course was punctuated by frequent recurrences, three biopsies taken over a period of nine years all showed benign Hodgkin's disease. Intercurrent illnesses were not prominent in our series and none of the deaths could be ascribed to them apart from the above cases of amyloid which were considered to be secondary to benign Hodgkin's disease.

Treatment was by local excision, radiotherapy, or nitrogen mustard, either singly or in combination. 
In four cases the disease was never satisfactorily controlled and ran a relentless course with death after illness lasting from 15 months to 12 years. The remaining patient has been observed for less than one year since radiotherapy; he is free from recurrence.

Chemotherapy was only employed as the initial treatment in two cases.

The period of follow-up has varied from a minimum of four years in all cases to a maximum of 26 years. Of 41 patients followed for five years, three died, giving a crude five-year survival rate of $93 \%$. Of 19 patients followed for 10 years, five died, giving a crude 10 -year survival rate of $74 \%$. A better estimate of the survival rate is given by the life table (Table II); calculated by this method, the five-year survival rate is $93 \%$ (standard error $=3.8 \%$ ) and the 10-year survival rate is $85 \%$ (standard error $=6.5 \%$ ).
DISCUSSION

INCIDENCE OF BENIGN HODGKIN'S DISEASE Because of the way in which the present series was collected, it was impossible to determine from our figures the incidence of benign Hodgkin's disease. Of 2,127 cases of tumours of lymphoid tissue reported in the literature (Jackson and Parker, 1947; Lumb, 1954; Symmers, 1958), $925(44 \%)$ were examples of Hodgkin's disease. Of these 113 were cases of benign Hodgkin's disease. The incidence of benign Hodgkin's disease is thus approximately $12 \%$ of all cases of Hodgkin's disease and $5 \%$ of all tumours of lymphoid tissue. Wright (1960) found that of 339 cases of Hodgkin's disease $26(8 \%)$ were examples of the benign form.

CLINICAL FEATURES The published series of benign Hodgkin's disease are summarized in Table III. The

TABLE II

LIFE TABLE OF SURVIVAL RATES IN BENIGN HODGKIN'S DISEASE

\begin{tabular}{|c|c|c|c|c|c|c|c|}
\hline $\begin{array}{l}\text { Time } \\
\text { in } \\
\text { Years }\end{array}$ & $\begin{array}{l}\text { No. of Cases } \\
\text { Alive at } \\
\text { Beginning of } \\
\text { Each Year }\end{array}$ & $\begin{array}{l}\text { No. of Cases } \\
\text { Alive but } \\
\text { Falling out of } \\
\text { Follow-up }\end{array}$ & $\begin{array}{l}\text { No. of Cases } \\
\text { Dying in } \\
\text { Given Year }\end{array}$ & $\begin{array}{l}\text { No. at Risk } \\
\text { in Given Year }\end{array}$ & $\begin{array}{l}\text { Probability of } \\
\text { Dying in Given } \\
\text { Year }\end{array}$ & $\begin{array}{l}\text { Probability of } \\
\text { Surviving through } \\
\text { Given Year }\end{array}$ & $\begin{array}{l}\text { Survival } \\
(\%)\end{array}$ \\
\hline 1 & 44 & 0 & 0 & 44 & 0 & 1 & 100 \\
\hline 2 & 44 & 0 & 1 & 44 & 0.02273 & 0.97727 & $97 \cdot 7$ \\
\hline 3 & 43 & 0 & 0 & 43 & 0 & 1 & $97 \cdot 7$ \\
\hline 4 & 43 & 0 & 1 & 43 & 0.02326 & 0.97674 & 95.5 \\
\hline 5 & 42 & 3 & 1 & 40.5 & 0.02469 & 0.07531 & 93.1 \\
\hline 6 & 38 & 8 & 0 & 34 & 0 & 1 & $93 \cdot 1$ \\
\hline 7 & 30 & 4 & 0 & 28 & 0 & 1 & $93 \cdot 1$ \\
\hline 8 & 26 & 3 & 1 & $24 \cdot 5$ & 0.04082 & 0.95918 & $89 \cdot 3$ \\
\hline 9 & 22 & 2 & 1 & 21 & 0.04762 & 0.95238 & 85.0 \\
\hline 10 & 19 & 5 & 0 & 16.5 & 0 & 1 & 85.0 \\
\hline
\end{tabular}

TABLE III

SEX AND AGE INCIDENCE OF BENIGN HODGKIN'S DISEASE

Author(s) Decade

\begin{tabular}{|c|c|c|c|c|c|c|c|c|c|c|}
\hline & & & & & & & & & & \\
\hline & & & $1 s t$ & $2 n d$ & $3 r d$ & $4 t h$ & $5 t h$ & $6 t h$ & $7 t h$ & $8 t h$ \\
\hline Jackson and Parker $(1947)^{1}$ & $\begin{array}{l}\mathbf{M} \\
\mathbf{F}\end{array}$ & $\begin{array}{l}30 \\
11\end{array}$ & 2 & 6 & 9 & 7 & 5 & 5 & 6 & 1 \\
\hline Jelliffe and Thomson (1955) ${ }^{1}$ & $\begin{array}{l}\mathbf{M} \\
\mathbf{F}\end{array}$ & $\begin{array}{l}6 \\
2\end{array}$ & - & 2 & 3 & 1 & - & 2 & 一 & - \\
\hline Wright $(1956)^{2}$ & $\begin{array}{l}\mathbf{M} \\
\mathbf{F}\end{array}$ & $\begin{array}{l}8 \\
2\end{array}$ & - & - & 3 & 3 & 1 & 3 & - & - \\
\hline Lumb and Newton $(1957)^{2}$ & $\begin{array}{l}\mathbf{M} \\
\mathbf{F}\end{array}$ & $\begin{array}{l}33 \\
3\end{array}$ & - & 6 & 15 & 5 & 3 & 4 & 3 & - \\
\hline Symmers (1958) ${ }^{1}$ & $\begin{array}{l}\mathbf{M} \\
\mathbf{F}\end{array}$ & $\begin{array}{l}44 \\
7\end{array}$ & 1 & 8 & 19 & 12 & 5 & 3 & 3 & - \\
\hline Wright $(1960)^{2}$ & $\begin{array}{l}\mathbf{M} \\
\mathbf{F}\end{array}$ & $\begin{array}{l}21 \\
3\end{array}$ & - & 2 & 11 & 2 & 7 & 2 & 一 & 一 \\
\hline Totals & $\begin{array}{l}\mathbf{M} \\
\mathbf{F}\end{array}$ & $\begin{array}{r}142 \\
28\end{array}$ & 3 & 24 & 60 & 30 & 21 & 19 & 12 & 1 \\
\hline Present series $^{1}$ & $\begin{array}{l}\mathbf{M} \\
\mathbf{F}\end{array}$ & $\begin{array}{l}31 \\
13\end{array}$ & 3 & 11 & 15 & 9 & 1 & 4 & - & 1 \\
\hline
\end{tabular}

'Age at onset. 'Age at diagnosis.

Lumb and Newton decades are from 0 to 10 years, 10 to 20 years, etc., whereas in the other series they are from 0 to 9 years, 10 to 19 years, etc. 
combined ratio men to women is $15 \cdot 1$ to 1 compared with that in the present series of 2.4 to 1 , but some of the published series may be biased because of the authors' connexions with the Armed Forces. Our present figures correspond closely with those of Jackson and Parker, and with those for Hodgkin's as a whole (1.8 to 1 in favour of males; collected series quoted by Hoster, Dratman, Craver, and Rolnick, 1948). Benign Hodgkin's disease is rare under the age of 10 years and has not been reported under the age of 5 years. It is most common between the ages of 15 and 35 years.

SITE OF ONSET AND CLINICAL STAGE Approximately three-quarters of all the cases reported in the literature initially involved only a single group of nodes, generally in the neck; our findings are similar. The existence of benign Hodgkin's disease outside lymph nodes is still uncertain. Jackson and Parker (1947), Marshall (1956) and Lumb and Newton (1957), all noted occasional involvement of the spleen and bone marrow clinically and Symmers (1958) stated that leukaemia could occur. Wright (1960) observed at necropsy infiltration of the liver and spleen by collections of lymphocytes and Sternberg-Reed cells, although elsewhere in the body the picture was that of classical Hodgkin's disease. In the present series the disease appeared to have involved bone marrow, spleen, spine, breast, and soft tissues of the buttock. In none of these was the involvement confirmed histologically, so that it is uncertain whether or not transition to the classical form had occurred; in some cases it appeared likely that it had. Cases showing splenomegaly or other evidence of spread beyond lymph nodes usually do badly.

Jackson and Parker (1947) state that constitutional symptoms do not occur. Three of our patients complained of weight loss and fever; in two of these the disease was apparently confined to a single group of nodes. One patient remained well for eight years following radiotherapy before transition to classical Hodgkin's disease occurred, and one remained well for four years following her initial course of treatment, before developing enlarged lymph nodes in the abdomen. The remaining patient ran a progressive course, dying three years after the onset of the disease. Four patients have been, or are, pregnant. Hartvigsen (1955) and Southam, Diamond, and Craver (1956) found that in patients with Hodgkin's disease who became pregnant the survival time was significantly reduced. Patients did badly particularly if their pregnancy coincided with an active phase of the disease. All the pregnancies in our series occurred during quiescent periods of the disease and, so far, no ill effects have been observed.

Two of our patients died from amyloidosis secondary to benign Hodgkin's disease. Castleman (1949) reports a similar case and Jackson and Parker(1947) report a case in which a transition from benigh $\overrightarrow{\overrightarrow{5}}$ to classical Hodgkin's disease had occurred. The association of amyloidosis with classical Hodgkin'동 disease is fairly well recognized, although the numberen of cases in the literature is only 63 (Dawson, 1960)

HISTOPATHOLOGICAL FEATURES While broadly fol $\stackrel{\text { ڤ }}{-}$ lowing the description of Jackson and Parker (1947), subsequent descriptions (Harrison, 1952; Lumb $\overrightarrow{\vec{\omega}}$ 1954; Smetana and Cohen, 1956; Wright, 1956 Lumb and Newton, 1957; Symmers, 1958; Pitcock요 Bauer, and McGavran, 1959; Wright, 1960) have differed in detail and emphasis, and new facts have्छ emerged.

Partial involvement of affected lymph nodes wa $\overrightarrow{0}$ first described by Jackson and Parker and stresse by Harrison, although Wright and Symmers believe. it to be infrequent. The present series has shown if to be surprisingly frequent and the retention of few surviving follicles to one side of the node in nछ way militates against the diagnosis.

The reticulin pattern varies widely. Harrison first drew attention to the reticulin and collagenou@ lobulation, an observation since confirmed by Lum and Wright as well as by the present findings Rappaport, Winter, and Hicks (1956) described 8 follicular lymphoma of Hodgkin's type of which they wrote 'were the background not follicular $\overrightarrow{\mathrm{o}} \overrightarrow{\mathrm{B}}$ nodular, one would not hesitate to classify most of these as Hodgkin's paragranuloma'. These author showed that the presence of a follicular pattern in. any type of tumour of lymphoid tissue was associated with an improved diagnosis. In our series, a fine network with or without superadded lobular and. follicular pattern was observed. There is thus ng single characteristic reticulin pattern in this disease although a gross increase in the amount of reticulig is against the diagnosis and in favour of classical Hodgkin's disease.

All authors stress that the bulk of the node is composed of small mature lymphocytes, which cannot be distinguished morphologically from those seen in normal nodes. Mitotic figures are not seew in these cells. The importance of the number of lymphocytes was first realized by Rosenthal (1936) and was the basis of his attempt to correlate hist $\sigma^{2}$ logical appearances and prognosis; this has recent been emphasized by Pitcock et al. (1959), who state that 'the length of survival correlated at the 5 宛 level of probability with the amount of lymphor background'. As a result of the present study, it now possible to lay down a lower limit of $75 \%$ fof the lymphocytes in the background. In most nodes they will total $90 \%$ or more of the background cells. 
Jackson and Parker stated that reticulum cells were present in varying numbers. Harrison commented on their virtual absence and Lumb thought that an increase in proliferating reticulum cells was associated with a liability to malignant change. The present study has shown that the number of reticulum cells is inversely proportional to the number of lymphocytes and is usually less than $10 \%$ of the total background cells. A percentage greater than $25 \%$, to our mind, precludes a diagnosis of benign Hodgkin's disease. The presence of mitotic figures in these cells has been shown to be of bad prognostic significance, and indeed we pay more attention to the number of reticulum cells and the presence of mitoses in them than to the lymphocytes. Sarcoid-like lesions have been reported in classical Hodgkin's disease by Smetana and Cohen (1956) and in benign Hodgkin's disease by Jackson and Parker (1947). These lesions were observed in seven biopsies in the present series and appear to be associated with a poor prognosis, although this was not the experience of Smetana and Cohen. SternbergReed cells are considered by all authors to be essential for the diagnosis of benign Hodgkin's disease, although Wright (1960) calls them 'reticulum cells'. They vary widely in number and are indistinguishable from those found in other forms of Hodgkin's disease. Lumb makes the reservation that giant forms are not common and Symmers thinks that the presence of bizarre forms forebodes transition to the classical form. On the whole they are present in small or moderate numbers only and are characteristically scattered singly or in loose clusters through the predominantly lymphocytic background. Harrison first drew attention to the constancy of mitotic figures in these cells, and nearly $3 \%$ of all Sternberg-Reed cells observed in the present series were in mitosis. Both normal and abnormal mitotic figures were observed. There is no direct correlation between mitotic activity and prognosis.

Jackson and Parker observed small numbers of eosinophils and plasma cells, a feature confirmed by later authors and ourselves. Caseation, necrosis, and capsular invasion do not occur. Paramyloid was a frequent finding in the present study.

Transition from benign to classical or sarcomatous Hodgkin's disease has been observed by most authors (Jackson and Parker, 1947; Custer and Bernhard, 1948; Lumb and Newton, 1957; Symmers, 1958; Wright, 1960), although the frequency with which this occurred has varied from series to series. Jackson and Parker estimated the frequency at about $20 \%$, and 10 of Lumb and Newton's 36 cases underwent this change. We were able to confirm this transition histologically in five cases, and its occurrence was suggested by the clinical course in a further four. Although Smetana and Cohen (1956) felt that this transition was more apparent than real and was due at least in part to misdiagnosis of the original biopsy, it now seems established as a definite occurrence in perhaps $25 \%$ of cases, and as the major cause of death. We believe that this change represents a phase in the natural history of the disease and is evidence for a close aetiological relationship between the two forms. It is impossible with the present state of knowledge to predict which cases will undergo this transition, but in our experience the presence of mitotic figures in reticulum cells and sarcoid-like areas are associated with a relatively poor prognosis. In most cases transition occurs between the fifth and fifteenth year of the disease, although Jackson and Parker (1947) describe a case in which it occurred in the twentyfourth year.

SURVIVAL RATES IN BENIGN HODGKIN'S DISEASE The comparative survival rates reported in the literature for the various types of Hodgkin's disease are given in Table IV. There seems some doubt as to the

\section{TABLE IV}

FIVE-YEAR SURVIVAL RATES AND HISTOLOGICAL CLASSIFICATION IN HODGKIN'S DISEASE

\begin{tabular}{|c|c|c|c|}
\hline Author(s) & Classification & $\begin{array}{l}\text { No. } \\
\text { of } \\
\text { Cases }\end{array}$ & $\begin{array}{l}\text { No. of } \\
\text { Cases } \\
\text { Surviving at } \\
\text { Five-year } \\
\text { Follow-up }\end{array}$ \\
\hline $\begin{array}{l}\text { Jackson and Parker } \\
(1947)^{1}\end{array}$ & $\begin{array}{l}\text { Paragranuloma } \\
\text { Granuloma } \\
\text { Sarcoma }\end{array}$ & $\begin{array}{r}28 \\
136 \\
32\end{array}$ & $\begin{array}{l}15(55 \%) \\
18(13 \%) \\
\text { Nil }\end{array}$ \\
\hline Peters $(1950)^{2}$ & $\begin{array}{l}\text { Early } \\
\text { Classical } \\
\text { Late } \\
\text { Atypical }\end{array}$ & $\begin{array}{l}20 \\
49 \\
24 \\
20\end{array}$ & $\begin{array}{l}15(75 \%) \\
25(57 \%) \\
11(50 \%) \\
5(25 \%)\end{array}$ \\
\hline $\begin{array}{l}\text { Jelliffe and Thomson } \\
(1955)^{1}\end{array}$ & $\begin{array}{l}\text { Grade I } \\
\text { Grade II } \\
\text { Grade III }\end{array}$ & $\begin{array}{r}5 \\
156 \\
10\end{array}$ & $\begin{array}{l}5(100 \%) \\
45(29 \%) \\
\text { Nil }\end{array}$ \\
\hline $\begin{array}{l}\text { Smetana and Cohen } \\
(1956)^{2}\end{array}$ & $\begin{array}{l}\text { Paragranuloma } \\
\text { Granuloma } \\
\text { Sarcoma }\end{array}$ & $\begin{array}{r}35 \\
308 \\
5\end{array}$ & $\begin{array}{l}\text { ( } 77 \% \text { net) } \\
(28 \% \text { net }) \\
\text { Nil }\end{array}$ \\
\hline $\begin{array}{l}\text { Lumb and Newton } \\
(1957)^{1}\end{array}$ & $\begin{array}{l}\text { Reticular lymphoma } \\
\text { Hodgkin's disease }\end{array}$ & $\begin{array}{r}29 \\
194\end{array}$ & $\begin{array}{l}27(93 \%) \\
67(35 \%)\end{array}$ \\
\hline Wright $(1960)^{2}$ & $\begin{array}{l}\text { Paragranuloma } \\
\text { Ordinary Hodgkin's } \\
\text { Hodgkin's sarcoma }\end{array}$ & $\begin{array}{r}19 \\
157 \\
10\end{array}$ & $\begin{array}{r}18(95 \%) \\
43(27 \%) \\
1(10 \%)\end{array}$ \\
\hline
\end{tabular}

${ }^{1}$ Survival period calculated from onset of symptoms

2Survival period calculated from biopsy or treatment

diagnosis in Hall and Olson's (1956) small series of five cases so these are excluded. From these figures it is readily apparent that these results are much better than the figures generally reported for Hodgkin's disease. 
This difference becomes much more significant if the 10-year survival rates of benign and classical Hodgkin's disease are compared. Twenty-one of the cases reported by Jackson and Parker (1947) were followed for 10 years; $10(48 \%)$ were alive at the end of this time. Smetana and Cohen (1956) reported a $55 \%$ 10-year survival rate. Wright (1956) followed five cases for 10 years with no deaths; but in a later series (1960) of 11 cases followed for the same period three died. Fourteen of 19 of our cases followed for 10 years survived this period. These results are very different from those quoted for Hodgkin's disease as a whole (see Table V) which

\section{TABLE V}

10-YEAR SURVIVAL IN HODGKIN'S DISEASE

\begin{tabular}{ll} 
Author(s) & $\begin{array}{l}\text { No. of Cases at } \\
10 \text {-year Follow-up }\end{array}$ \\
\hline
\end{tabular}

Unselected for histological type

Uddströmer (1934)

Slaughter and Craver (1942)

Merner and Stenstrom (1947)

Healy, Amory, and Friedman (1955)

Peters and Middlemiss (1958)

494 (Nil)

$265(3 \%)$

$185(8 \%)$

$216(6 \%)$

$139(29 \%)$

Excluding cases of benign Hodgkin's disease

Jackson and Parker (1947)

Lumb (1954)

$136(1 \%)$

$123(2 \%)$

vary between nil and $29 \%$. In the series of Jackson and Parker, and of Lumb, where cases of benign Hodgkin's disease are excluded, only one of 136 and two of 123 cases respectively survived 10 years.

The results of Peters and Middlemiss (1958) are much better than average and must be attributed to a better technique of treatment. It is their practice to irradiate prophylactically the lymph node regions adjacent to those actually affected. In the present series treatment was undertaken at many centres so that the results cannot be a reflection of a single technical advance in radiotherapy.

It is, however, difficult in a disease with such a slow remittent course to assess accurately the effect of treatment in the individual case. The striking difference in the recurrence rates after surgery alone, and after radiotherapy, observed by both Wright and ourselves suggests that radiotherapy does in fact influence the course of the disease. For this reason we advise biopsy-excision followed by radiotherapy.

Peters (1950) first showed a correlation in Hodgkin's disease between the extent of the disease when the patient was first seen and the survival rate. Because of the frequency with which benign Hodgkin's disease is initially localized to a single group of nodes, it has been suggested that the improved prognosis is merely a reflection of the localization of the disease. If the present series is combined with that of Wright (1956) and the others $\stackrel{0}{\vec{\sigma}}$ listed in Table IV, a total of 151 cases is obtained; of these 127 survived five years. This gives a crude five-year survival rate of $84 \%$. Two hundred and fifty-nine cases of Hodgkin's disease, clinically 듬 localized to a single lymphatic region, mostly $\frac{\bar{c}}{\mathrm{~T}}$ unselected for histological type, are listed in Table VI. (Lumb and Newton exclude cases of what they

\section{TABLE VI}

FIVE-YEAR SURVIVAL IN HODGKIN'S DISEASE ACCORDING TO CLINICAL STAGE

\begin{tabular}{llcc} 
Author(s) & $\begin{array}{l}\text { Clinical } \\
\text { Stage }\end{array}$ & $\begin{array}{l}\text { No. of } \\
\text { Cases }\end{array}$ & $\begin{array}{l}\text { Five-year } \\
\text { Survival: } \\
\text { No. of Cases }\end{array}$ \\
\hline Jelliffe and Thomson (1955) & I & 32 & $19(59 \%)$ \\
& II & 47 & $28(60 \%)$ \\
Sellers (1957) & III & 92 & $3(3 \%)$ \\
& I & 100 & $57(57 \%)$ \\
Lumb and Newton (1957) & II & 141 & $49(35 \%)$ \\
& I & 174 & $20(12 \%)$ \\
Peters and Middlemiss (1958) & I & 67 & $35(52 \%)$ \\
& III & 60 & $27(40 \%)$ \\
& III & 60 & $5(7 \%)$ \\
& & 70 & $39(71 \%)$ \\
& 91 & $14(15 \%)$
\end{tabular}

call 'reticular lymphoma'.) Of these, 154 survived five years, giving a crude five-year survival rate of $59 \%$. There is thus a considerable difference in $\stackrel{\square}{\mathbb{Q}}$ prognosis between cases of Hodgkin's disease $\overrightarrow{\vec{P}}$ localized to one site and cases of benign Hodgkin's $\frac{0}{3}$ disease, irrespective of the extent of the disease when first seen. These arguments in no way invalidate Peters' conclusions and it appears to be an established fact that the prognosis in classical Hodgkin's ? disease is much better when the condition is localized $\frac{5}{3}$ to a single group lymphatic region.

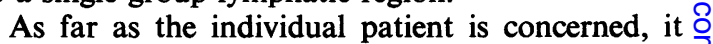
is extremely difficult to state dogmatically whether a cure has been effected in benign Hodgkin's disease. 음 Certainly recurrences and death after a quiescent $D$ period of 10 years or longer are not uncommon. Jackson and Parker (1947) report a patient who died N in the twenty-seventh year of his illness; following his initial course of treatment he had remained 0 well for 24 years. The same authors also report a $\omega$ patient surviving 35 years with recurrences in the seventh and twenty-seventh years. We believe that 0 progression is ultimately inevitable in the absence $\Phi$ of treatment but that with energetic radiotherapy a permanent cure is possible.

This work was made possible by the many colleagues $\stackrel{\vec{D}}{\circ}$ who sent us cases and helped us so generously with the $\vec{\Phi}$ follow-up; to them we are deeply grateful. We should $\frac{a}{\sigma}$ also like to thank Professor I. Doniach for much helpful advice. 


\section{REFERENCES}

Bonenfant, J.-L. (1954). La lympho-réticulose médullaire chronique maligne avec syndrome Hodgkinien (paragranulome). Bull. Ass. franc. Cancer, 41, 296.

Castleman, B. (1949). Pathological discussion on Cabot case 35391 of the Massachusetts General Hospital. New Engl. J. Med., 241, 499.

Custer, R. P., and Bernhard, W. G. (1948). The interrelationship of Hodgkin's disease and other lymphatic tumors. Amer. J. med. Sci., 216, 625.

Dawson, P. J. (1960). Benign Hodgkin's Disease. M.D. Thesis, Cambridge.

Hall, C. A., and Olson, K. B. (1956). Prognosis of the malignant lymphomas. Ann. intern. Med., 44, 687.

Harrison, C. V. (1952). Benign Hodgkin's disease (Hodgkin's paragranuloma). J. Path. Bact., 64, 513.

Hartvigsen, F. B. (1955). Hodgkin's disease and pregnancy. Acta radiol. (Stockh.), 44, 317 .

Healy, R. J., Amory, H. I., and Friedman, M. (1955). Hodgkin's disease: a review of 216 cases. Radiology, 64,51 .

Hoster, H. A., Dratman, Mary B., Craver, L. F., and Rolnick, H. A. (1948). Hodgkin's disease, 1832-1947. Cancer Res., 8, 1.

Jackson, H. (1937). The classification and prognosis of Hodgkin's disease and allied disorders. Surg. Gynec. Obstet., 64, 465.

- (1939). Hodgkin's disease and allied disorders. New Engl. J. Med., 220, 26.

and 639.

- - (1947). Hodgkin's Disease and Allied Disorders, Ch. 1, p. 3. Oxford University Press, New York.

Jelliffe, A. M., and Thomson, A. D. (1955). The prognosis in Hodgkin's disease. Brit. J. Cancer, 9, 21.

Lumb, G. (1954). Tumours of Lymphoid Tissue, Ch. 7, p. 58. Livingstone, Edinburgh.

- , and Newton, K. A. (1957). Prognosis in tumors of lymphoid tissue: an analysis of 602 cases. Cancer (Philad.), 10, 976.

Marshall, A. H. E. (1956). An Outline of the Cytology and Pathology, of the Reticular Tissue, Ch. 4, p. 164. Oliver and Boyd, Edinburgh.
Merner, T. B., and Stenstrom, K. W. (1947). Roentgen therapy in Hodgkin's disease. Radiology, 48, 355.

Peters, M. Vera (1950). A study of survivals in Hodgkin's disease treated radiologically. Amer. J. Roentgenol., 63, 299.

- , and Middlemiss, K. C. H. (1958). A study of Hodgkin's disease treated by irradiation. Ibid, 79, 114.

Pitcock, J. A., Bauer, W. C., and McGavran, M. H. (1959). Hodgkin's disease in children: a clinicopathological study of 46 cases. Cancer (Philad.), 12, 1043.

Rappaport, H., Winter, W. J., and Hicks, Ethel B. (1956). Follicular lymphoma: a re-evaluation of its position in the scheme of malignant lymphoma, based on a survey of 253 cases. Ibid, 9, 792.

Robb-Smith, A. H. T. (1947). In S. C. Dyke (Ed.) Recent Advances in Clinical Pathology, Ch. 34, pp. 360 and 367. Churchill, London.

Rosenthal, S. R. (1936). Significance of tissue lymphocytes in the prognosis of lymphogranulomatosis. Arch. Path. (Chicago), 21, 628 .

Sellers, A. H. (1957). A Statistical Review of Hodgkin's Disease. Ontario Department of Health.

Slaughter, D. P., and Craver, L. F. (1942). Hodgkin's disease: fiveyear survival rate; value of early surgical treatment; notes on four cases of long duration. Amer. J. Roentgenol., 47, 596.

Smetana, H. F., and Cohen, B. M. (1956). Mortality in relation to histologic type in Hodgkin's disease. Blood, 11, 211.

Southam, C. M., Diamond, H. D., and Craver, L. F. (1956). Pregnancy during Hodgkin's disease. Cancer (Philad.), 9, 1141.

Symmers, W. St. C. (1958). In R. W. Raven (Ed.) Cancer, Vol. 2, Ch. 24, p. 478. Butterworth, London.

Trautmann, F. (1954). Benigne chronische Lymphomatose. Artzl. Wschr., 9, 1093 and 1113.

- (1959). Benign chronische Lymphomatose. Ther. d. Gegenw., $98,112$.

Uddströmer, M. (1934). On the occurrence of lymphogranulomatosis (Sternberg) in Sweden 1915-31 and some considerations as to its relation to tuberculosis. Acta tuberc. scand., Suppl. I.

Wright, C. J. E. (1956). Hodgkin's paragranuloma. Cancer (Philad.), 9, 773 .

- (1960). The 'benign' form of Hodgkin's disease (Hodgkin's paragranuloma). J. Path. Bact., 80, 157. 